\title{
表面技術とイオン交換
}

和 田 洋 六*

\section{Technique of Surface Finishing and Ion Exchange}

\section{Hiromutsu WADA*}

Key Words : Ion Exchange Resin, Electro Dialysis Membrane, RO Membrane, UV Ozone Oxidation, Recycling of Water

表面処理における水処理は環境保全の見地から高度処理，リサイクル化あるいは薬品を使わない処 理技術が求められている。ここでは，これらの目的に使われるイオン交換樹脂や電気透析膜を用いた 水処理技術について解説する

\section{1.はじめに}

イオン交換現象は 1850 年にイギリスの H.S. Thompsonにより発見された。それ以後, 粘土, 鉱物, 岩石などのイオン交換反応が土壤学者らに よって 1950 年ごろまで研究された。水処理で使 用されている合成樹脂製のイオン交換樹脂は 1935 年にイギリスの B. A. Adams と E. L. Holmesによって製造方法が報告されたのをきっ かけに 1938 年にドイツで商品化された。続いて, 1940 年にアメリカで工業規模で商品化され産業 界に広く普及した。

イオン交換樹脂と同じ分子構造の電気透析膜は 1950 年に入って優れた性能をもつものが造られ るようになり，主に，海水の濃縮による食塩製造 などに利用されるようになった。これらのイオン 交換樹脂や電気透析膜は水処理における物質の分 離・精製・濃縮の目的に広く利用されている。

現在, イオン交換樹脂は火力原子力発電所, 半 導体製造工場，表面処理工場，製糖工場などで使

*日本ワコン侏（テ240-0013 神奈川県横浜市保土ヶ谷区帷子 町 1-44)

Nihon Wacon Co, Ltd (1-44, Katabira-cho, Hodogayaku, Yokohama-shı, Kanagawa 240-0013)
われ，電気透析膜は食塩製造工場，海水淡水化な どに用いられている。いずれも私達の生活や産業 には必須の素材である。

本稿では表面処理におけるイオン交換樹脂と電 気透析膜を用いた実用的な用排水処理技術につい て述べる。

\section{2.イオン交換樹脂と電気透析膜の違い}

イオン交換樹脂は直径 $0.3 \sim 1.2 \mathrm{~mm}$ 程度の球 で電気透析膜はイオン交換樹脂と同じ高分子物質 を $0.1 〜 0.2 \mathrm{~mm}$ 程度の膜に加工したものである。 同じ分子構造でありながら両者の形の違いが性質 や取り扱い方法を全く別のものにしている。

図 1 にイオン交換樹脂内のイオンの動きを示す。 イオン交換樹脂処理は, 通常, 陽イオン交換樹脂 と陰イオン交換樹脂を別々の容器に充填し，これ を直列につないで使用する。一例として，塩分を 含んだ水を陽イオン交換樹脂塔と陰イオン交換樹 脂塔の順に通水したとしよう。水中の塩分 $(\mathrm{NaCl})$ の $\mathrm{Na}$ イオンは $\mathrm{H}$ 型陽イオン交換樹脂の $\mathrm{H}$ イオンと交換吸着するので，この段階では中 性塩の $\mathrm{NaCl}$ が酸 $(\mathrm{HCl})$ に変わる。次に, 陰イオ ン交換樹脂層に移流した $\mathrm{HCl}$ は $\mathrm{OH}$ 型陰イオン 交換樹脂の $\mathrm{OH}$ イオンと交換するので $\mathrm{H}_{2} \mathrm{O}$ とな 


\section{$\mathrm{NaCl}$ 필 $\mathrm{HCl} \Rightarrow \mathrm{H}_{2} \mathrm{O}$}

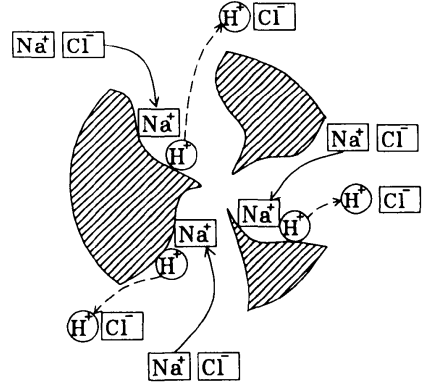

(1) 陽イオン交换樹脂

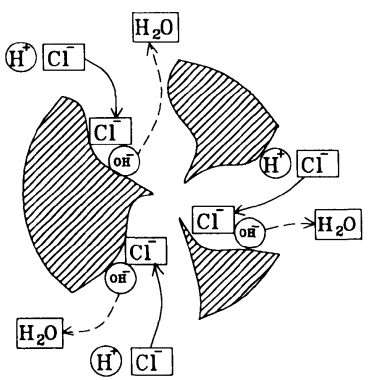

(2) 陰イオン交換樹脂

図 1 イオン交換樹脂内のイオンの動き

る。これがイオン交換樹脂による脱イオンの原理

で，化学反応式で示すと式(1)(2)となる。

$$
\begin{aligned}
& \mathrm{R}-\mathrm{SO}_{3} \mathrm{H}+\mathrm{NaCl} \rightarrow \mathrm{R}-\mathrm{SO}_{3} \mathrm{Na}+\mathrm{HCl} \quad \cdots(1) \\
& \mathrm{R}-\mathrm{N} \cdot \mathrm{OH}+\mathrm{HCl} \rightarrow \mathrm{R}-\mathrm{N} \cdot \mathrm{Cl}+\mathrm{H}_{2} \mathrm{O} \quad \cdots \cdot(2)
\end{aligned}
$$

イオン交換樹脂がもっている $\mathrm{H}^{+}$と $\mathrm{OH}^{-}$交 換基の量は有限であるから, 反応が平衡に達する と式は右へ進まなくなる。この場合は, 陽イオン 交換樹脂には塩酸などの酸 $\left(\mathrm{H}^{+}\right)$を，陰イオン交 換樹脂には水酸化ナトリウムなどのアルカリ $\left(\mathrm{OH}^{-}\right)$を接触させれば式(1)(2)の反応が逆方向に 進む。これがイオン交換樹脂再生の原理で, 化学 式で示すと式(3)(4)となる。

$$
\begin{aligned}
& \mathrm{R}-\mathrm{SO}_{3} \mathrm{Na}+\mathrm{HCl} \rightarrow \mathrm{R}-\mathrm{SO}_{3} \mathrm{H}+\mathrm{NaCl} \cdots(3) \\
& \mathrm{R}-\mathrm{N} \cdot \mathrm{Cl}+\mathrm{NaOH} \rightarrow \mathrm{R}-\mathrm{N} \cdot \mathrm{OH}+\mathrm{NaCl} \cdots(4)
\end{aligned}
$$

図 2 は陽イオン交換樹脂塔と陰イオン交換樹脂 塔に塩類を含んだ水を流し，脱塩と再生を行う工 程を模式的に示したものである。

陽イオン交換樹脂塔を出た処理水は微量の酸を 含んでいるので $\mathrm{pH}$ は 2 2 程度の酸性を示す。 通常，水の中には炭酸水素イオン $\left(\mathrm{HCO}_{3}^{-}\right)$が 30〜 $50 \mathrm{mg} / \mathrm{L}$ 含まれる。図 2 の方式では，炭酸 水素イオンはすべて陰イオン交換樹脂塔で交換吸 着するので樹脂に負荷がかかる。したがって，こ の方法は小規模の装置に採用される。ところが, 炭酸水素イオンを含んだ酸性の水は空気に暴露す るか減圧すればこれを除くことができる。私達は 酸性で炭酸を含んだ清涼飲料水をかきまぜると炭 酸成分が早くぬけることを体験するが，これと同 じ現象である。これにより，陰イオン交換樹脂に

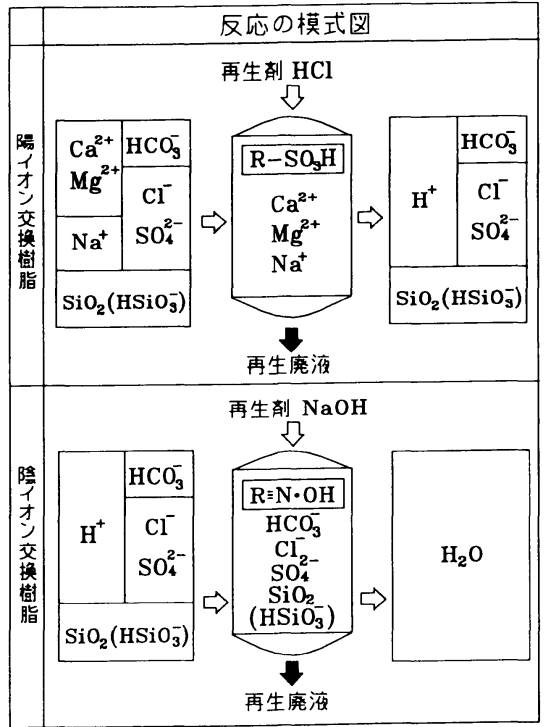

図 2 脱塩と再生の模式図

対する負荷を軽減できるので樹脂の寿命を長くす ることができる。

図 3 は上記の目的のために陽イオン交換樹脂塔 と陰イオン交換樹脂塔の間に脱炭酸塔を設けた処 理方式である。この配列はイオン交換樹脂塔が 2 塔あり，脱炭酸塔が 1 塔なので 2 床 3 塔式とよん でいる。

図 4 に電気透析膜内のイオンの動きを示す。

陽イオン透析膜と陰イオン透析膜の両側にプラ ス電極とマイナス電極をおき，これに直流電気を 流しながら，食塩 $(\mathrm{NaCl})$ 水を通したとすると陽 イオン透析膜は陽イオンだけを通過させるのでプ 


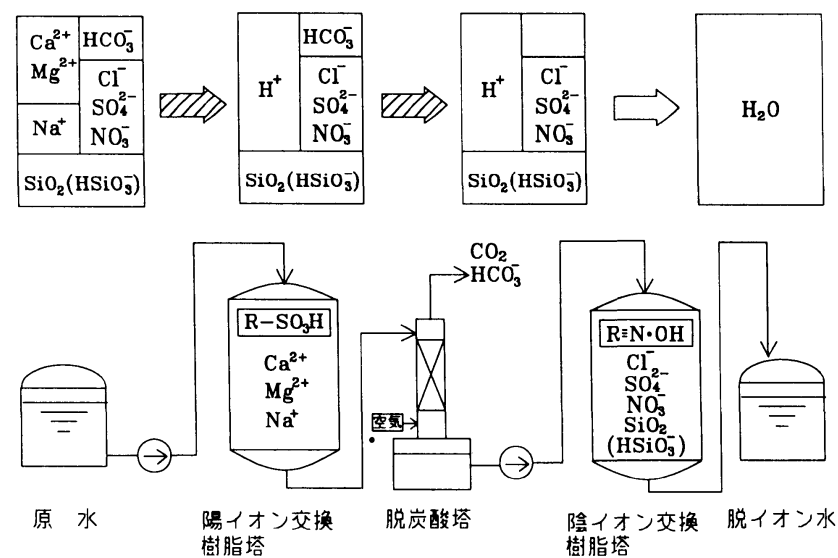

図 32 床 3 塔式イオン交換装置例

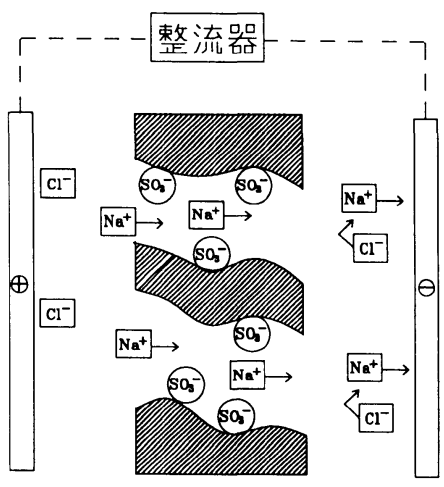

(1)陽イオン透析膜

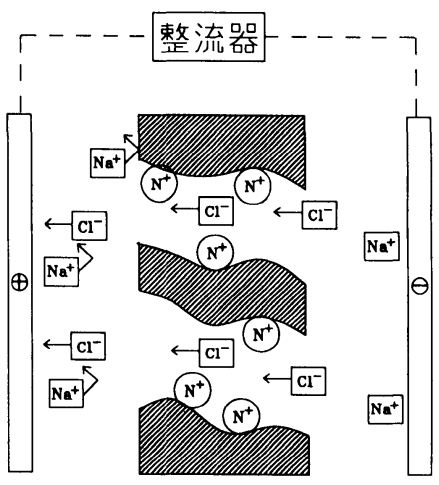

(2)陰イオン透析膜

図 4 電気透析膜内のイオンの動き

ラス極側には塩化物イオン $\left(\mathrm{Cl}^{-}\right)$だけが残り，マ イナス極側にはナトリウムイオン $\left(\mathrm{Na}^{+}\right)$が移動す る。これと反対に，陰イオン透析膜は陰イオンだ けを通過させるのでプラス極側に塩化物イオン $\left(\mathrm{Cl}^{-}\right)$が集まり，マイナス極側にはナトリウムイ オン $\left(\mathrm{Na}^{+}\right)$が残る。次に, 図 5 のように陽イオン 透析膜と陰イオン透析膜を重ねて,この両側にプ ラス極とマイナス極をおいて直流電気を流し，下 から薄い食塩水を流したとしよう。

食塩水が下から上に流れる間に，ナトリウムイ オンと塩化物イオンは中央の隙間に集まり, 濃縮 水として上方向に流れ出る。一方, 電極側ではイ オンが移動してしまうので希薄液となって上方向 に流出する。これが電気透析の原理で, イオン交

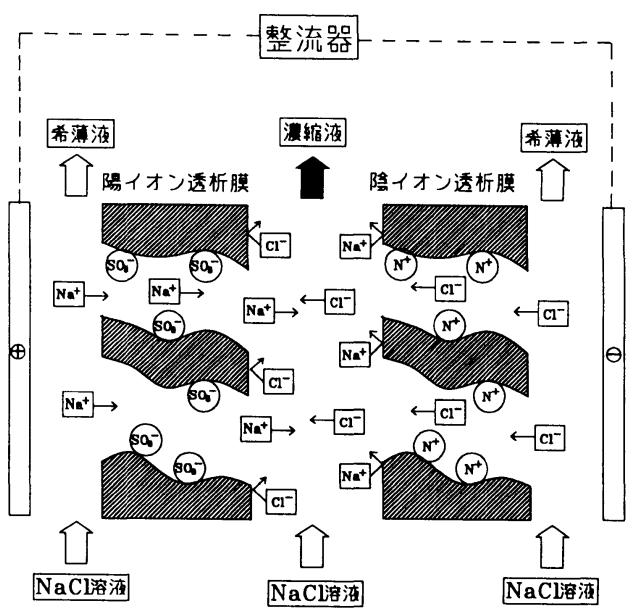

図 5 電気透析の原理 
換反応をしないところに特徴がある1)。このよう に, 電気透析膜法では電気的な作用によってイオ ンが膜を通過するだけで水中の塩分の濃縮と脱塩 を行うことができるので，イオン交換樹脂のよう に「飽和」という現象がおこらない。したがって, 電気透析膜法では薬品による再生の必要がない。

\section{3. 薬品を使わない高度処理法}

用水や廃水を処理するには多くの化学薬品が使 われる。しかし，この方法は処理水中に溶解塩類 や処理の段階で意図しなかった有害な副生成物が 発生したり，廃棄物としてのスラッジが多く発生 するので環境保全の見地から好ましくない。とこ ろが, 活性炭, 逆浸透膜, 光オゾン酸化処理, イ オン交換樹脂処理などを組み合わせた高度処理法 を適用すると化学薬品を使用しないで水の浄化や 排水のリサイクル化が可能となる。

活性炭は多くの有機物を吸着するので水の高度 処理に使われている。ところで，活性炭を使えば どんな有機物でもよく吸着するかといえばそうで もなく処理する物質によって差がある。

一般に芳香族化合物は脂肪族化合物に比較して

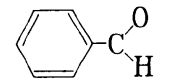

ベンズアルデヒド 分子量 106.1

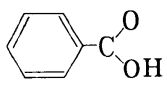

安息香酸 分子量 122.1<smiles>CC=O</smiles>

アセトアルデヒド

分子量 44.1<smiles>CC(=O)O</smiles>

酢 酸

分子量 60.1
図 6 芳香族化合物と脂肪族化合物の構造例 活性炭によく吸着される。一例として，図6に示 すベンズアルデヒドの吸着量はアセトアルデヒド の 9 倍あり, 安息香酸は酢酸の 4 倍程度の吸着量 である2)。

図 7 はアルコールの吸着量と分子量の関係を示 したものである。アルコールは炭素数が増えて分 子量が大きくなると活性炭への吸着量が増加する。 活性炭は水に不溶の疎水性物質なので吸着する側 の物質も疎水性のものほど吸着されやすくなる。 したがって，有機物の炭素数が増えたりアルキル 基が長くなれば疎水性を増し，水に溶けにくくな るので活性炭への吸着性が強くなる。

図 8 に浸透圧と逆浸透圧の関係を示す。(1)の浸 透のように半透膜を隔てて塩水と淡水をひとつの 容器に入れたとすると, 淡水は塩水を薄めようと して塩水側に移動する。これは自然現象で両方の 濃度がつりあうまで続く。(2)の浸透十平衡は両方 の濃度が平衡に達したときの様子である。このと きの水面の高低差が浸透圧である。ちなみに海水 の浸透圧はおよそ $2.5 \mathrm{MPa}$ である。次に(3)の逆

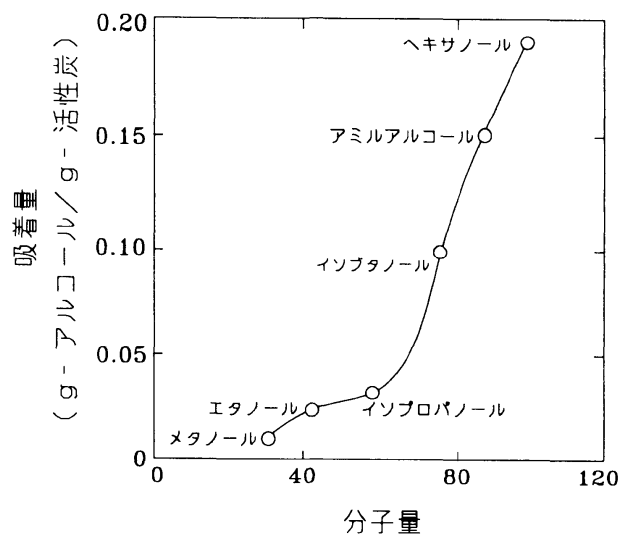

図 7 アルコールの分子量と活性炭吸着量の関係

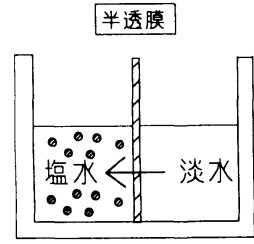

(1) 浸透

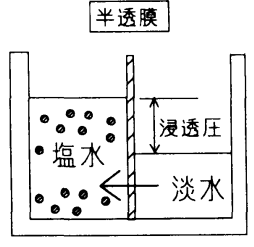

(2) 浸透 + 平衡

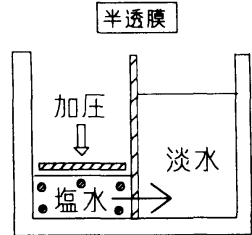

(3) 逆浸透

図 8 浸透圧と逆浸透圧 


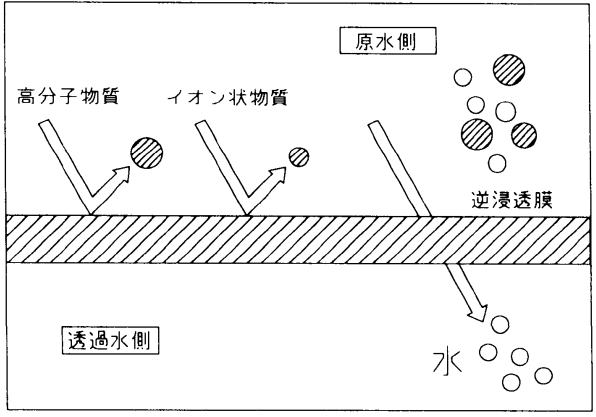

図 9 逆浸透膜面の物質移動

浸透のように塩水側に圧力を加えると塩水の中の 水分子だけが淡水側に移動するので塩水から淡水 を分離することができる。この原理を応用すれば 水に含まれる不純物を膜処理によって除くことが できる。実際の逆浸透膜処理で用いる圧力は溶液 のもつ浸透圧の約 2 倍の圧力が必要である。した がって, 海水の淡水化処理では 5 6 $\mathrm{MPa}$ の圧力 が必要となる。

図 9 は逆浸透膜面における物質移動の概念図で ある。逆浸透膜は基本的に水分子しか通過させな いので高分子物質や銅，ニッケル，亜鉛などのイ オン状物質の透過は阻止できる。これにより，水 に含まれるほとんどの不純物は水に加圧するだけ で分離できるようになる。このように，逆浸透膜 における分離の原理は単純であるが，図９の原水 側では複雑な濃縮, 物質移動および流動などの現 象が複合しておこるので，実用化に当ってはこれ らの要素を考慮しなければならない。

一例として，膜面を閉塞させる直接の原因とな る懸濁物質は前処理で十分に除去することが重要 で，原水の FI 值 (Fouling Index)を 4 以下にす る必要がある。私達が毎日飲んでいる水道水は浄 水場で処理されたきれいな水であるが，この FI 值を測定すると 4.5〜 6.0 程度を示すので，その まま逆浸透膜処理するのは難しい。

膜面に析出しやすいシリカやカルシウム成分の 多い水処理では濃縮率と溶解度の関係をよく検討 する。pH 7 におけるシリカ $\left(\mathrm{SiO}_{2}, \mathrm{HSiO}_{3}{ }^{-}\right)$の水 に対する溶解度はおよそ $100 \mathrm{mg} / \mathrm{L}$ である。飲料 水の中には通常, $20 \sim 30 \mathrm{mg} / \mathrm{L}$ シリカが含まれ ているので，5倍に濃縮すれば膜面にシリカがス
ケールとなって析出する。この場合の濃縮率は 4 倍以下に保つなどの対策が必要である。

海水のカルシウム硬度は約 $400 \mathrm{mg} / \mathrm{L}$ である。 これを逆浸透膜で処理するときは, 通常, 原水側 のカルシウム濃度をスケール析出限界の $670 \mathrm{mg} /$ L 以下に管理する。これは，濃縮倍率に換算する と 1.67 倍 $(670 / 400=1.67)$ である。濃縮倍率がこ れ以上大きくなるとカルシウムスケールが膜面に 析出する可能性が大となるので実際には 1.5 倍程 度の濃縮倍率で管理するとよい。

オゾンには酸化力がある。オゾンに $253.7 \mathrm{~nm}$ の紫外線を照射すると式(5)(6)のように更に強い酸 化力のあるヒドロキシルラジカル $(\mathrm{HO} ・)$ を生成 するのでほとんどの物質を酸化することができる。

$$
\begin{aligned}
& \mathrm{O}_{3}+h \nu(\lambda<310 \mathrm{~nm}) \rightarrow[\mathrm{O}]+\mathrm{O}_{2} \\
& {[\mathrm{O}]+\mathrm{H}_{2} \mathrm{O} \rightarrow 2 \mathrm{HO} \cdot \ldots \ldots \ldots \ldots \ldots \ldots \ldots \ldots \ldots}
\end{aligned}
$$

一例として，メチルアルコールは式(7)〜 (9)のよ うにアルデヒドや酸を経て最終的に $\mathrm{CO}_{2}$ と $\mathrm{H}_{2}$ $\mathrm{O}$ に分解される ${ }^{3)}$ 。

$$
\begin{aligned}
& \mathrm{CH}_{3} \mathrm{OH}+2 \mathrm{HO} \rightarrow \mathrm{HCHO}+2 \mathrm{H}_{2} \mathrm{O} \\
& \mathrm{HCHO}+2 \mathrm{HO} \cdot \rightarrow \mathrm{HCOOH}+\mathrm{H}_{2} \mathrm{O} \\
& \mathrm{HCOOH}+2 \mathrm{HO} \rightarrow \mathrm{CO}_{2}+2 \mathrm{H}_{2} \mathrm{O} .
\end{aligned}
$$

排水のリサイクルに光オゾン酸化装置を用いる 場合は活性炭吸着塔を組み合わせるとさらに良い 結果が得られる4)。

図 10 は光オゾン酸化と活性炭を用いた高度処 理例である。原水槽の水はポンプで反応槽におく る。反応槽には $184.9 \mathrm{~nm}$ と $253.7 \mathrm{~nm}$ の波長の 紫外線を発生する低圧水銀ランプが設置されてい

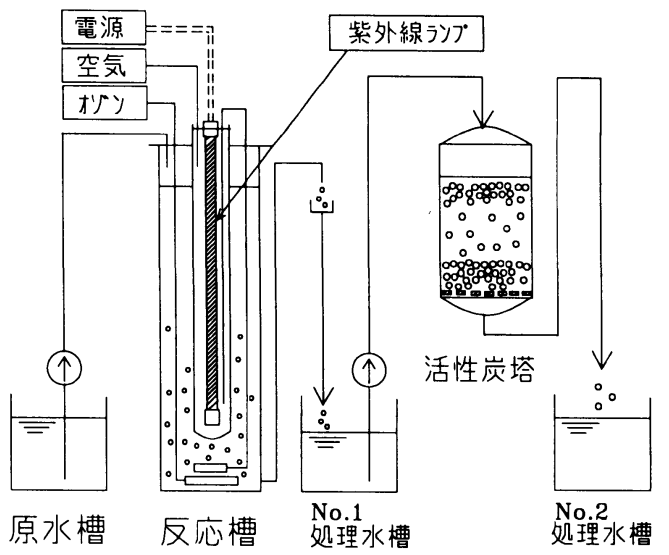

図 10 光オゾン酸化と活性炭を用いた高度処理 


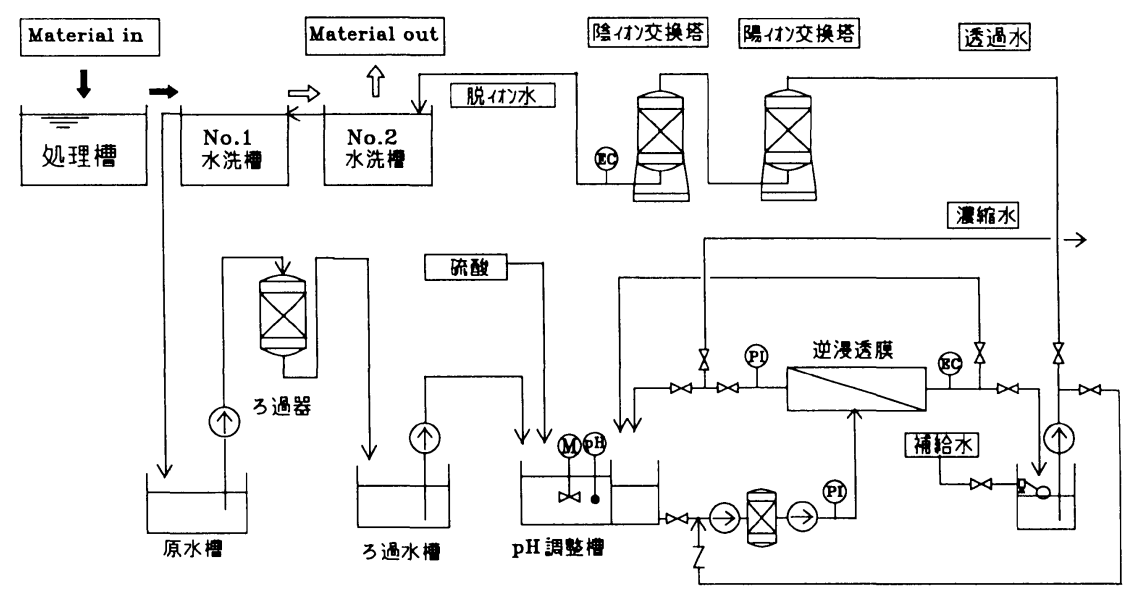

図 11 逆浸透膜法とイオン交換樹脂法を組み合わせた表面処理排水の再利用フローシート

る。オゾン発生器で発生させたオゾンは槽低部か ら散気する。紫外線ランプを点灯すると温度が上 昇するので冷却の目的で空気を送るが, この空気 は $184.9 \mathrm{~nm}$ の紫外線にあたると一部がオゾン化 されるので，これも反応槽下部から散気して有効 利用を図るようにしている。このようにすると光 オゾン酸化反応が進みやすくなるが, 対象物質に よっては十分ではない。その場合は，後段に活性 炭塔を設けると更に良好な結果が得られる。活性 炭塔の前に光オゾン酸化装置を置くと活性炭の寿 命が 5 ～10 倍長持ちすることがある。これは，光 オゾン酸化により大きな分子量の物質が活性炭に 吸着しやすい物質に変化したのと前工程のオゾン 酸化由来の酸素の影響で活性炭層中に生成付着し た微生物の代謝作用が活発となり, 活性炭の吸着 作用に生物学的分解作用が付加されたためである。

\section{4. イオン交換樹脂を利用した水のリサイク ル}

イオン交換樹脂は水中のイオンを吸着するので 純度の高い処理水を得ることができる。しかし， イオン濃度があまり高い溶液を取り扱うとすぐに 飽和に達してしまうので，ひとつの目安として塩 類濃度 $1,000 \mathrm{mg} / \mathrm{L}$ 以下の水を処理するのがよ $\left(^{5)}\right.$ 。溶解塩類濃度が低ければ直接イオン交換樹 脂処理できるが，濃度が高い場合には前段に逆浸 透膜装置を設置すると溶解塩類濃度が $5,000 \mathrm{mg} /$
L 以上あってもイオン交換樹脂処理が適用できる。 一例として, 逆浸透膜装置を用いると溶解塩類の 95\%程度は除去できるので原水の塩類濃度が $7,500 \mathrm{mg} / \mathrm{L}$ あっても, この処理水の塩類濃度は $375 \mathrm{mg} / \mathrm{L}$ となる。この段階まで脱塩すればイオ ン交換樹脂処理が可能となる。

図 11 は逆浸透膜法とイオン交換樹脂法を組み 合わせた表面処理排水の再利用装置フローシート 例である。図 11 では処理薬品による溶解塩類濃 度の増加を防ぐ目的で，ろ過と $\mathrm{pH}$ 調整をしただ けで，中和，凝集，沈殿処理などは行っていない。 こうすると処理薬品の節約，発生スラッジの減少 化，浸透圧上昇の防止，高圧ポンプの小型化が図 れるなどの利点がある。

図 12 に光オゾン酸化とイオン交換樹脂法を組 み合わせた表面処理排水の再利用装置フローシー 卜例を示す。濃度の低いシアンやクロム排水に対 して光オゾン酸化処理をしてイオン交換樹脂処理 をするとイオン交換樹脂の寿命が長くなる。この ようにすると，イオン交換樹脂の性質をうまく利 用できるので樹脂の再生頻度が少なくなり，省資 源で経済的な運転管理ができる ${ }^{6)}$ 。

\section{5. 電気透析膜による脱塩と濃縮}

図 13 に電気透析膜による濃縮と脱塩装置のフ ローシートを示す。陽イオン透析膜と陰イオン透 析膜を交互に重ねて両端に電極を装着し，型枠で 


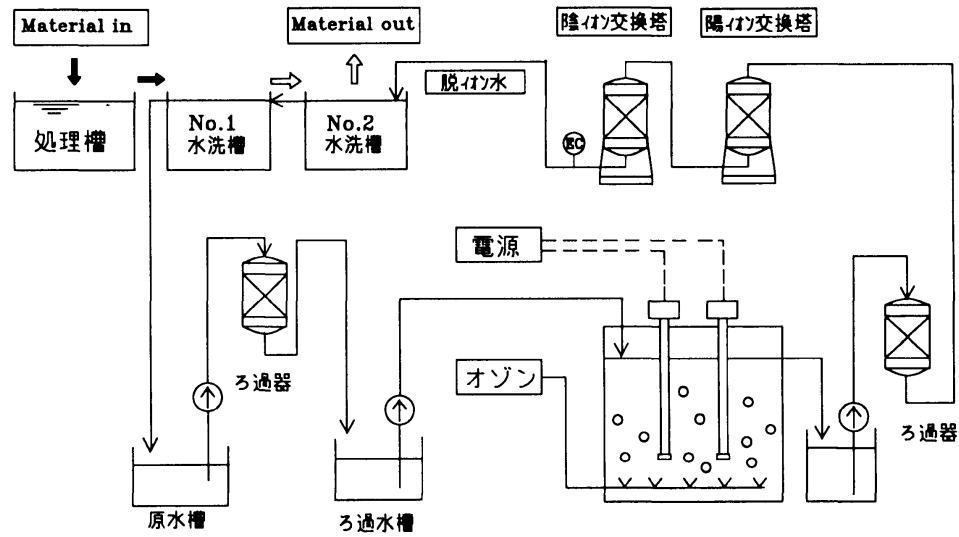

図 12 光オゾン酸化法とイオン交換樹脂法を組み合わせた表面処理排水の再利用フローシート

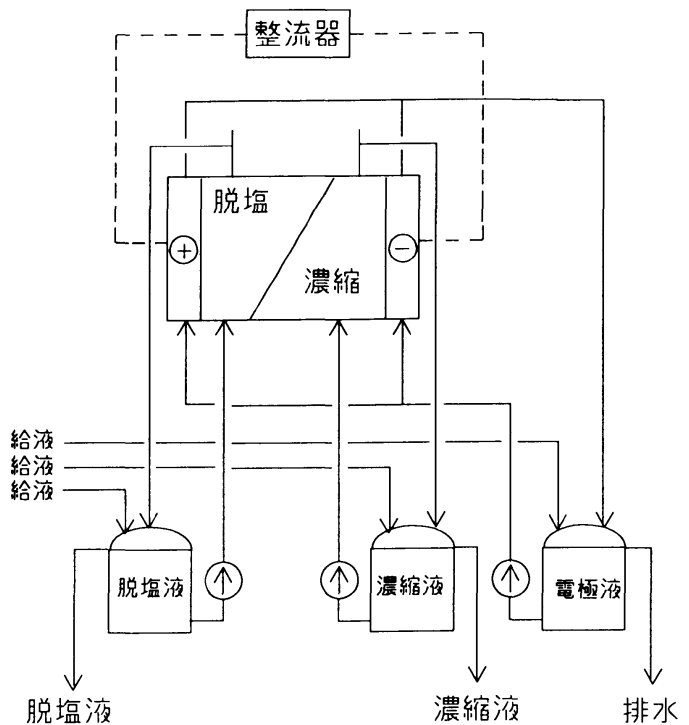

図 13 電気透析膜による濃縮と脱塩

締め付けて電気透析室を構成する。一例として, 脱塩液槽と濃縮液槽に同じ塩類濃度の溶液を入れ て電極液(硫酸ナトリウム溶液など) に電流を通し ながら，それぞれの液を循環すると脱塩槽の水は 脱塩されて純度の高い水となる。一方, 濃縮液槽 の水は原水中のイオンが移動してくるので濃度が 高くなる。この装置を使えば溶液の濃縮と水の脱 塩精製が同時に行えるので目的によって使い分け ることができる。海水から飲料水を得るには脱塩 水を取ればよく, 海水を濃縮するには濃縮水を集 めればよい。

電気透析膜法の特徵は逆浸透膜法と違って物質

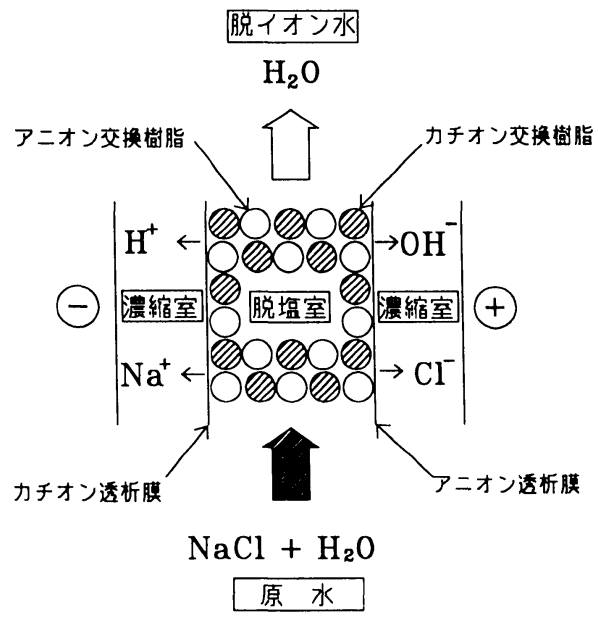

図 14 電気透析膜とイオン交換樹脂法を組み合わせた 脱塩装置
の分離に高い圧力を必要としない点にある。膜面 間の隙間は 1〜2 mm とかなり狭いが，原水の前 処理は逆浸透膜装置ほど厳密でなくてもよい。こ れらのことから, 運転, 維持管理は電気透析膜装 置のほうが容易と思われる。

図 14 は電気透析膜とイオン交換樹脂を組み合 わせた脱塩装置例である。内部は陽極，陰極の間 にカチオン透析膜, アニオン透析膜があり, 膜の 間にイオン交換樹脂が充填されている。塩類を含 んだ原水は下方から入り上方に移動する間に，ま ず, $\mathrm{NaCl}$ がイオン交換樹脂に吸着する。次に, 膜の両側に直流電流を印加すると, イオン交換樹 脂に吸着したイオンは電位勾配に従い, 陽イオン $\left(\mathrm{Na}^{+}\right)$は陰極側へ, 陰イオン $\left(\mathrm{Cl}^{-}\right)$は陽極側へ移 
動し, ついには電気透析膜を透過して隣の濃縮室 に移動する。同時に，カチオン交換膜とアニオン 交換膜の界面では水が解離して, 生成した $\mathrm{H}^{+}$イ オンと $\mathrm{OH}^{-}$イオンにより，イオン交換樹脂が再 生される。これにより, 脱イオン水が連続的に製 造できる7)。最近の電気透析膜とイオン交換樹脂 を組み合わせた脱塩装置では, 脱イオン効率の向 上や装置のコンパクト化をめざして，イオン交換 樹脂の代わりにイオン交換不織布を用いたり，イ オン交換体を電気透析膜ではさんで渦巻き状にし たスパイラル型のものなどが発表されている。

これらの装置は塩類濃度の高い水や污濁した水 の取り扱いには適さないが，ある程度まで脱塩し た水を更に精製して純度の高い水を造る場合には 適した装置である。イオン交換樹脂と電気透析膜 の長所を組み合わせたこの脱塩装置はすでに多く の水処理装置に組み込まれ実用化されている。

\section{6.おわりに}

イオン交換は地球上で太古の昔から営まれてい た自然現象である。イオン交換媒体を介してある 一定の法則に従いイオンが脱着したり透過する現 象は単純なようであるが複雑な面もありなかなか 興味深い。イオン交換樹脂や電気透析膜の特性を
うまく利用して他の水処理技術と組み合わせると これまでになかったいくつかの新しい処理法が実 現する。表面処理に打ける最近の水処理は環境保 全の見地から化学薬品を使用しない高度処理やリ サイクル化技術が求められている。イオン交換現 象を応用した水処理はこれらの目的達成のために 必須の技術であり，今後更に重要な位置をしめる と考えられる。

(1999-4-30，受理)

\section{文献}

1 ）和田洋六；造水の技術, p. 99（地人書館, 1996)

2) 和田洋六；水のリサイクル(応用編), p. 49 （地人書 館, 1992）

3 ) 和田洋六, 直井利之, 黒田康弘; 日本化学会誌, (2) , 130 (1998)

4 ) 和田洋六, 直井利之, 黒田康弘 ; 日本化学会誌, (3), 219 (1997)

5 ）和田洋六；表面技術, 49，44（1998）

6 ) 和田洋六, 直井利之, 黒田康弘; 日本化学会誌, (4), 306 (1995)

7 ) 堀江浩文 ; 化学工学, 62, 264（1998）

8 ) Alan Whitley, David Drummonds and Bob Hamilton ; Ultrapure Water, Nov. 32 (1994) 